\title{
The Effect of Poor Implementation of Tax Policies on Developing Economies. A study of Nigerian Economy, (1999-2010).
}

\author{
Echekoba Felix Nwaolisa \\ Nwaolisa@yahoo.com \\ echekobaf@gmail.com
}

Lecturer; Department of Banking and Finance

Nnamdi Azikiwe University, Awka

\author{
Ezu Gideon Kasie \\ gideon_lake@yahoo.com \\ 08032932828
}

Lecturer; Department of Banking and Finance

Nnamdi Azikiwe University, Awka

\begin{abstract}
This study investigated 'The Effect of Poor Implementation of Tax Policies on Developing Economies; A Study of Nigerian Economy, (1999-2010)'. Past studies have largely focused on challenges and prospects of taxation in Nigeria. This study found it expedient to explore the rationale behind poor tax system in Nigeria. To achieve the objective of the study, the following objectives were set out by the researcher: to examine the causes of double taxation by different levels of government on Nigerian citizens and non-citizens alike: to examine the perceived seriousness of tax evasion vis-à-vis various legal offences. Analytical research method was used since the researcher made use of secondary data obtained from the office of Federal Inland Revenue Service. The results show that that the expected revenue mapped out by Federal Inland Revenue Service could not be met due to poor implementation of tax policies in Nigeria. It was recommended that the Nigerian Tax system should be simple (easy to understand by all), certain (its laws and administration must be consistent) and clear (stakeholders must understand the basis of its imposition).
\end{abstract}

Key words: Tax evasion, Double taxation, Tax regime

\section{Introduction}

A tax policy represents key resource allocator between the public and private sectors in a country. It is usually imposed on individuals and 
entity that make up a country. The funds provided by tax are used by the states to support certain state obligations such as education systems, health care systems, pensions for the elderly, unemployment benefits, and public transportation. A nation's tax system is often a reflection of its communal values or the values of those in power. To create a system of taxation, a nation must make choices regarding the distribution of the tax burden, who will pay taxes, how much they will pay and how the taxes collected will be spent. In Nigeria, the taxation system dates back to 1904 when the personal income tax was introduced in Northern Nigeria before the unification of the country by the colonial masters. It was later implemented through the Native Revenue Ordinances to the western and Eastern regions in 1917 and 1928, respectively.

Among other amendments in the 1930s, it was later incorporated into Direct Taxation Ordinance No. 4 of 1940. Since then different governments have continued to try to improve on Nigeria's taxation system. The general opinion among scholars is that Nigeria's fiscal regime is characterized by unnecessary complex, distortions and largely inequitable taxation laws that have limited application in the formal sector that dominates the economy. Given the foregoing, it is important that Nigeria adopt a taxation policy that would enhance national development. The Nigerian tax system is basically structured as a tool for revenue collection. This is a legacy from the pre-independence government. Based on 1948 British tax laws and have been mainly static since enactment. The need to tax personal incomes throughout the country prompted the Income Tax Management Act (ITMA) of 1961. In Nigeria, Personal Income Tax (PIT) for salaried employment is based on a 'Pay As You Earn' (PAYE) system, and several amendments have been made to the 1961 ITMA Act. For instance, in 1985 PIT was increased from N600 or 10 per cent of earned income to N2,000 plus 12.5 per cent of income exceeding N6,000. In 1989, a 15 percent withholding tax was applied to savings deposits valued at N50,000 or more while tax on rental income was extended to cover chartered vessels, ships or aircraft. In addition, tax on the fees of directors was fixed at 15 percent. These policies were geared to achieving effective protection for local industries, greater use of local raw materials, generating increased government revenue among others. Since the 
implementation of the Structural Adjustment Programme (SAP), however, taxes have been used to enhance the productivity and competitiveness of business enterprises.

Consequently, attention has been focused on promoting exports of manufactures and reducing the tax burden of individuals and companies. In line with this change in policy focus, many measures were undertaken. These involved, among others, reviewing custom and excise duties, continuing with the reduction of company and income taxes, expanding the range of tax exemptions and rebates, introducing capital allowance, expanding the duty drawback scheme and manufacturing-in-bond scheme, abolishing excise duty, implementing VAT, monetizing fringe benefits and increasing tax relief to lowincome earners.

\section{The Problem}

Efficient tax system is tantamount to economic growth and development. Any country that treats it with hand glove is heading towards a precipice. In Nigeria, tax evasion and other related tax offences are very prevalent. Citizens and non-citizens alike evade tax with reckless abandon owing to the government attitude towards taxation in Nigeria. Whereas, tax evaders are dealt with ruthlessly in advanced countries of Europe, America and Asia, it is regarded as a simple offence which cannot attract a heavy penalty in Nigeria. In Nigeria, the only group of people that pay tax as at when due are civil and public servants because their taxes are deducted from the source. However, business men and companies that control billions or millions of naira pay little or no tax.

Moreover, because of lack of efficient tax system in Nigeria, there is a conflict of interest amongst the Federal, State and Local Government in tax collection which culminates into double taxation which does not augur well with the Nigerian Economy. The main reason why different levels of government feel non-challant about efficient tax system is because of their belief that there must be a revenue from the oil sector which will be shared at the end of every month. Therefore this study seeks to tackle such lackadaisical attitudes. 


\section{Objectives of the Study}

The broad objective of this study is to evaluate the effect of poor implementation of tax policies on developing economies using Nigerian economy as a case study. The specific objectives of this study are as follows

1. to examine the causes of double taxation by different levels of government on Nigerian citizens and non-citizens alike.

2. examine the perceived seriousness of tax evasion vis-à-vis various legal offences;

3. to assess the effect of corruption on the actualization of efficient tax policy in Nigeria.

4. to evaluate different methods which tax authorities can employ in ensuring prompt payment of tax by Nigerians and nonNigerians who work in the country.

5. to compare the Nigeria Tax Policy and USA Tax Policy so as to suggest the best possible means of solving tax evasion in Nigeria.

\section{Hypotheses}

A hypothesis is a tentative answer to a research question that is to be subjected to further empirical validation. For the purpose of this study, two hypotheses will be stated in null form

H0: Poor implementation of tax policies in Nigerian do not encourage tax invasion.

H0: Double taxation discourages investors from investing in Nigeria.

\section{Significance of the Study}

A major problem in Nigerian tax regime is the multiplicity of taximposing and tax-collecting entities at federal, state, and local government levels. Like the Nigerian federation itself, there is little clarity on jurisdictional competencies and indeed, many observers doubt whether there is genuine fiscal federalism in Nigeria. This research work will be significant to the following stakeholders:

Government: Different levels of government in Nigeria should be able to harmonize and design a better tax regime which will no longer encourage double taxation inefficiencies. 
Investors: Manufacturers and owners of small and medium scale industries will find this study useful because it will discuss extensively the danger inherent in tax evasion.

\section{Scope of the Study}

This study covers prominent tax polices initiated by the Government of Nigeria and its subsequent implementation. It equally compares the tax regime penalties in USA and Nigeria. Federal Inland Revenue Services was used as a focal point.

\section{Theoretical Framework}

Taxation is basically the process of collecting taxes within a particular location. In this regard, tax has been defined as "a monetary charge imposed by the Government on persons, entities, transactions or properties to yield revenue". Okodo (2001) defined tax as "the enforced proportional contributions from persons and property, levied by the State by virtue of its sovereignty for the support of Government and for all public needs".

Taxes may be direct or indirect and may be imposed on individual basis, on entities, on assets and on transactional basis. In Nigeria, taxes are imposed on the individuals such Personal Income Tax and Development Levy. On companies such as, Companies Income Tax, Petroleum Profit Tax, Education Tax and Technology Levy. On Transactions such as, Value Added Tax, Capital Gains Tax, Stamp Duty, Excise Duty, Import Duty and Export Duty. On Assets such as Property Tax.

\section{Objectives of the Nigerian Tax System}

Oshinowo (2001) stated that the Nigerian tax system is expected to contribute to the well-being of all Nigerians and taxes, which are collected by Government should directly impact on the lives of the citizens. This can be accomplished through proper and judicious utilisation of the revenues collected by government. In line with the above, there are certain objectives, which the Tax System is expected to achieve. These objectives include: 


\section{To Promote Fiscal Responsibility and Accountability}

Okorie (1999) asserts that one of the primary objectives of the National Tax Policy is to create a tax system, which ensures that Government transparently and judiciously accounts for the revenue it generates through taxation by investing in the provision of infrastructure and public goods and services. Where this is in place, Nigerians would have a tax system that they can fully relate to and which is a tool for National Development.

\section{To facilitate economic growth and development.}

Agbade (2003) stated that the overriding objective of the Nigerian tax system should be to achieve economic growth and development. As such, the system should allow for stimulation of the economy and not stifle growth, as it is only through sustained economic growth that the potential ability to offer improvements in the well-being of Nigerians will arise. The tax system should therefore not discourage investment and the propensity to save. Taxes should not be a burden, but should be applied proactively with other policy measures to stimulate economic growth and development.

\section{To provide the government with stable resources for the provision of public goods and services}

For Nigeria to pursue an active development agenda and carry out the basic functions of government, its tax system should generate sufficient resources for government to provide basic public goods and services (e.g. education, healthcare, infrastructure, security etc., (Bulus, 2010). It is therefore a primary objective of taxation to provide the government with resources that it shall invest in judicious expenditure that will ultimately improve the well-being of all Nigerians.

\section{To Address Inequalities in Income Distribution}

Nigeria's tax system should take cognisance of our peculiar economic circumstances and seek to narrow the gap between the highest and lowest income groups. Those with the highest incomes should pay the highest percentage of tax and tax revenue should be utilised to provide Nigerians with affordable social amenities, basic infrastructure and other utilities. 


\section{To Provide Economic Stabilisation}

Nigeria should use its tax system to minimise the negative impacts of volatile booms and recessions in the economy and also to help complement the efforts of monetary policy in order to achieve economic stability.

\section{Impediments to Efficient Tax System in Nigeria Evasion of customs duty}

Customs duties are an important source of revenue in the developing countries. The importers purport to evade customs duty by (a) underinvoicing and (b) mis-declaration of quantity and product-description. When there is ad valorem import duty, the tax base is reduced through under-invoicing. Mis-declaration of quantity is more relevant for products with specific duty.

\section{Smuggling}

Egwu (2002) defined smuggling as importation or exportation of foreign products through unauthorized route. Smuggling is resorted to for total evasion of leviable customs duties as well as for importation of contraband items. A smuggler does not have to pay any customs duty since the products are not routed through an authorized or notified Customs port and therefore, not subjected to declaration and payment of duties and taxes.

Anya, (2007) stressed that Nigeria has one of the worst porous borders in the world stretching from Borno, Zamfara, Kogi and Cross-River states thus making it possible for smugglers to have a field day.

\section{Government response}

Tax evasion also depends on the efficiency of the tax administration. Corruption by the tax officials often renders control of evasion difficult. Tax administrations resort to various means for plugging in scope of evasion and increasing the level of enforcement. When the president and governors receives huge amount of money from federal allocation, it makes them lackadaisical about engaging in internally generated revenue which involves taxation thereby encouraging tax evasion. 


\section{Corruption by tax officials}

Corrupt tax officials cooperate with the tax payers who intend to evade taxes. When they detect an instance of evasion, they refrain from reporting in return for illegal gratification or bribe. Corruption by tax officials is a serious problem for the tax administration in a huge number of developing and southern European countries.

\section{The United States Tax System}

Taxes in the United States are administered by literally hundreds of tax authorities. At the Federal level there are three tax administrations. Alcohol, tobacco, and firearms taxes are administered by the Alcohol and Tobacco Tax and Trade Bureau (TTB). All other taxes on domestic activities are administered by the Internal Revenue Service (IRS). Taxes on imports (customs duties) are administered by U.S. Customs and Border Patrol. TTB is part of the Department of Justice and CBP belongs to the Department of Homeland Security. The IRS is a division within the U.S. Department of Treasury. Organization of state and local tax administrations varies widely. Every state maintains a tax administration. A few states administer some local taxes in whole or part. Most localities also maintain a tax administration or share one with neighbouring localities, Steve (2002). The United States Government has fortified their borders especially the border between the United States and Mexico where drug barons and other economic saboteurs ply their trade.

\section{Celebrated cases of tax evaders in the United States of America}

- 1932-1939: Al Capone served seven years of an 11-year sentence in federal prison on Alcatraz Island for tax evasion. He was let out of jail early while suffering with the advanced stages of Syphilis.

- 1963: Joe Conforte, a brothel owner, serves two and a half years in prison, convicted for the crime of income tax evasion.

- Cornelius Gallagher (D-NJ) pleaded guilty to tax evasion, and served two years in prison.

- 1974: Otto Kerner, Jr. (D) Resigned as a judge of the Federal Seventh Circuit Court District after conviction for bribery, mail 
fraud and tax evasion while Governor of Illinois. He was sentenced to 3 years in prison and fined $\$ 50,000$.

- 1982: Frederick W. Richmond (D-NY) was convicted of tax evasion and possession of marijuana. He served 9 months.

- 1987: Robert Bernard Anderson (R) former United States Secretary of Treasury (1957-1961) pled guilty to tax evasion while operating an offshore bank and sentenced for 2 years.

- Harry Claiborne, Federal District court Judge from Nevada, was impeached by the House and convicted by the Senate on two counts of tax evasion. He served over one year in prison.

- 1991: Harry Mohney, founder of the Déjà Vu strip club chain, served three years in prison for tax evasion.

- 1992: Catalina Vasquez Villalpando (R), Treasurer of the United States, pled guilty to obstruction of justice and tax evasion and was sentenced for 2 years in prison.

- Nicolas Castronuovo is the owner of the Florida pizza parlor where Senator Robert Torricelli was caught on an FBI wiretap soliciting contributions in 1996. Nicolas Castronuovo and his grandson Nicholas Melone later pleaded guilty to evading the government of $\$ 100,000$ and was sentenced for 3 years in prison.

- 1995: Webster Hubbell, (D) Associate Attorney General, pled guilty to mail fraud and tax evasion. He is sentenced to 21 months in prison.

- 1996: Heidi Fleiss was convicted of federal charges of tax evasion and sentenced to 7 years in prison. After two months she was released to a halfway house, with 370 hours of community service.

- 2002: James Traficant (D-OH) was convicted of ten felony counts including bribery, racketeering and tax evasion and sentenced to 8 years in prison.

- 2002: The Christian Patriot Association, an "ultra-right-wing group", was shut down after convictions for tax fraud and tax evasion.

- 2005: Duke Cunningham (R-CA) pleads guilty to charges of conspiracy to commit bribery, mail fraud, wire fraud and tax 
evasion in what came to be called the Cunningham scandal. He was sentenced to over eight years.

- 2008: Actor Wesley Snipes was sentenced to 3 years in jail for tax evasion.

- 2008: Charles Rangel (D-NY) failed to report $\$ 75,000$ income from the rental of his villa in Punta Cana, Dominican Republic and was forced to pay $\$ 11,000$ in back taxes.

- $\quad$ Jack Abramoff , lobbyist, was found guilty of conspiracy, tax evasion and corruption of public officials in three different courts in a wide ranging investigation. Currently serving 70 months and fined \$24.7 million

- $\quad$ Jared Carpenter, Counsel of Republicans for Environmental Advocacy, pled guilty to income tax evasion, and received 45 days, plus 4 years probation.

Source: Federal Inland Revenue Services Archive, Washington DC (2010)

Unfortunately, in Nigeria due to lax in efficient tax system and over reliance in the down stream sectors of the economy, there is no celebrated cases of prominent Nigerian's that was jailed for tax evasion nor any company was fully penalized for evading tax.

\section{Research Method and Results}

Analytical research method was used since the researcher made use of secondary data obtained from the office of Federal Inland Revenue Service.

Table 1: Total Tax Collection for March, 2011(in billion), oil and non-oil.

\begin{tabular}{|l|l|l|l|}
\hline Category & $\begin{array}{l}2011 \quad \text { FIRST } \\
\text { Monthly } \\
\text { Target (N'b) }\end{array}$ & $\begin{array}{l}\text { Actual } \\
\text { Collection } \\
\text { (N'b) }\end{array}$ & $\begin{array}{l}\text { \% OF Contribution To } \\
\text { Total Collection }\end{array}$ \\
\hline Oil tax & 140.9167 & 165.8922 & 60.11 \\
\hline Non-oil tax & 150.1250 & 110.0688 & 39.89 \\
\hline Total & 291.0417 & 275.9610 & 100.00 \\
\hline
\end{tabular}

Source: FIRS, Reporting and Statistics Department 
The table above shows that the expected revenue mapped out by Federal Inland Revenue Service could not be met due to poor implementation of tax system in Nigeria. If different levels of government engage in strict implementation of tax regime, there will be efficient tax system in the country.

Table 4.2 : Tax Revenue Collection by Tax Types.

\begin{tabular}{|l|l|l|l|}
\hline $\begin{array}{l}\text { Tax } \\
\text { Types }\end{array}$ & $\begin{array}{l}\text { Annual Tax } \\
\text { Target }(\mathbf{N b})\end{array}$ & $\begin{array}{l}\text { Actual } \\
\text { Collection }(\mathbf{N b})\end{array}$ & $\begin{array}{l}\text { \% Contribution } \\
\text { to the Total } \\
\text { Collection }\end{array}$ \\
\hline PPT & 140.9167 & 165.8922 & 60.11 \\
\hline CIT & 63.2500 & 38.4155 & 13.92 \\
\hline GI & 7.4167 & 0.7456 & 0.27 \\
\hline CGT & 0.2917 & 0.0089 & 0.01 \\
\hline SD & 1.2500 & 0.5973 & 0.22 \\
\hline VAT & 64.1666 & 61.6073 & 22.32 \\
\hline EDT & 8.0833 & 3.3752 & 1.22 \\
\hline PIT & 4.5000 & 5.1623 & 1.87 \\
\hline POL & 0.4167 & 0.0474 & 0.02 \\
\hline NITDEF & 0.7500 & 0.1093 & 0.04 \\
\hline TOTAL & 291.0417 & 275.9610 & 100.00 \\
\hline
\end{tabular}

Source: FIRS, Planning, Reporting and Statistics Department

The table above equally shows that the target revenue which the Federal Inland Revenue Service projected could not be met because of governments non-challant attitude towards taxation.

The result of the above analysis shows that poor implementation of tax system in Nigeria has led loss of huge revenue to the government.

\section{Recommendations}

1. Taxpayers should understand and trust the tax system, and this can only be achieved if Nigerian tax policy keeps all taxes simple, creates certainty through considerable restrictions on the need for discretionary judgements, and produces clarity by educating the public on the application of relevant tax laws. It is therefore 
imperative that the Nigerian Tax system should be simple (easy to understand by all), certain (its laws and administration must be consistent) and clear (stakeholders must understand the basis of its imposition).

2. To enable a high level of compliance, the economic costs of time required, and the expense which a taxpayer may incur during the procedures for compliance, shall be kept to the absolute minimum at all times. Furthermore, taxpayers should be regarded as clients with the right to be treated respectfully. The convenience of the taxpayer and minimal compliance cost should guide the design and implementation of every tax in Nigeria.

3. A key feature of a good tax system is that the cost of administration must be relatively low when compared to the benefits derived from its imposition. There must therefore be a proper cost - benefit analysis before the imposition of any taxes and the entire machinery of Tax Administration in Nigeria should be efficient and cost effective.

\section{References}

Agbade, J.N. (2003). Technological innovation and Taxation in Nigeria: An evaluation of Citizens' perceptions, American Academy of Financial Management.

Anya, B. H. (2007). Leadership and Tax Management - A case study based on SAS Cargo, Master's Thesis, Stockholm School of Economics, p.7.

Bulus, H.I (2010). Survey of Nigerian Tax systems: Citizens option. ABI/INFORM Global, p. 4A-13A.

Egwu, T.U. (1993). Doing Your Research Project - A guide for firsttime researchers in education and social science, 3rd Ed, Open University Press, Buckingham. 
FIRS WDC, (2010). Celebrated Cases of Tax offenders in the United State of America. Washington Press.

Okodo, J. W. (2001). Research methods in the social sciences, Harper Collins, New York.

Okorie, S.U (1999). Nigerian Tax Regime: Problems and Prospects. Journal of Accountancy. 21, p. 1573-1624.

Oshinowo, D. B., (2001). Realizing the gains from Efficient Taxation: Cost, Pricing, and Payment Choice. Journal of Money, Credit, and Banking, vol. 33, No. 2, pp. 216-234.

Steve, J. M. (2002). Cannons of Taxation. Johnjacobs Publishers. Enugu 